\title{
REPRESENTAÇÃO DA MULHER NA PUBLICIDADE: UM ESTUDO DE CASO DO VÍDEO CÂMERA TÍMIDA, DA MARCA DOVE
}

\author{
Jussara Cugler ${ }^{1}$ \\ Eliane Basilio de Oliveira ${ }^{2}$
}

Resumo: O objetivo deste trabalho é analisar a representação da mulher no vídeo "Câmera Tímida" da marca Dove, veiculado no canal Youtube. O trabalho envolve a apresentação do conceito de gênero, sua relação com a publicidade e análise de elementos formais da peça estudada. Por fim, a pesquisa mostra que a marca Dove, de uma maneira sutil, reforça estereótipos relacionados ao universo feminino.

Palavras-chave: Gênero, publicidade, feminismo, estereótipos.

Abstract: The aim of this article is to analyse the representation of woman in the Dove's video "Camera shy", broadcast on the Youtube. This essay consists on a presentation of the concept of gender, its relations with publicity and an analysis of the formal elements of the video. This research shows that the brand Dove, although in a subtle way, reinforces stereotypes related to the female universe.

Keywords: Gender, publicity, feminism, stereotypes.

\section{Introdução}

A mídia é capaz de informar, educar, reforçar valores, comportamentos, auxiliar na construção e reprodução das relações feminimas e masculinas. Ela desempenha um papel relevante na educação e no desenvolvimento da cultura, pois promove troca simbólica e material entre os indivíduos em esfera global. Os discursos veiculados nas diferentes mídias ganham status de verdade na sociedade e contribuem para moldar comportamentos femininos e masculinos.

É possível observar este poder da mídia na padronização da beleza feminina reproduzida pelas imagens e discursos veículados em anúncios e em capas de revistas, que passam a ser desejadas por mulheres e homens. Este padrão amplia cada vez mais a rentabilidade da indústria da beleza, que produz e vende cosméticos, perfumes, produtos de higiene, dieta, saúde etc. Em meio a um cenário que indica certa padronização dos ideais de beleza, no entanto, algumas empresas têm apostado em uma representação mais plural da mulher. Para entender como essas marcas estão incorporando e usando a diversidade da beleza feminina e seus impactos nas relações de gênero, este trabalho busca responder à seguinte questão: quais são as representações da beleza feminina que

\footnotetext{
${ }^{1}$ Aluna do curso de Publicidade e Propaganda do Centro Universitário Curitiba (Unicuritiba).

${ }^{2}$ Socióloga (PUC-PR), mestre em Educação pela Universidade Federal do Paraná (UFPR), professora do curso de Publicidade \& Propaganda no Centro Universitário Curitiba (Unicuritiba) e do curso de Jornalismo na Universidade Positivo (UP).
} 
a marca Dove constrói na campanha "Câmera Tímida" e quais são as estratégias publicitárias utilizadas?

O texto foi organizado em duas partes. Na primeira, discute o conceito de gênero e a relação deste com a publicidade. Na segunda, faz-se o estudo da campanha "Câmera Tímida" a partir da metodologia da análise do conteúdo, levando em conta aspectos relacionados às convenções formais da publicidade, tais como imagens, personagens, ambientação.

\section{Definição de gênero e o feminismo}

Antes de definirmos gênero, são necessárias algumas palavras sobre o feminismo. Segundo Louro et al. (2007, p. 11), o movimento teve duas grandes fases. A primeira, a partir do movimento sufragista do final do século XIX, visou permitir o voto às mulheres, ampliar seu acesso à educação e ao mercado de trabalho; e a segunda fase, a partir dos anos 1960, teve como objetivo maior ênfase à luta contra as desigualdades de gênero nas mais diversas esferas da sociedade. Destas discussões dependem o conceito de gênero.

Joan Scott (apud TELES, 2006, p.45) revela que ainda não há uma "tradição teórico-epistemológica sólida" para gênero, ou seja, não existe consenso quanto sua definição. Por conta disso, muitos acabam por confundir gênero com mulher, mas a autora alerta para o fato de que gênero implica a relação entre homens e mulheres. $O$ termo não deve ser confundido com feminismo. Gênero explica as diferenças das relações sociais, culturais, econômicas e políticas entre o homem e a mulher. O feminismo é um movimento organizado de mulheres que visa "questionar os paradigmas que determinam a supremacia masculina em detrimento da autonomia e da emancipação das mulheres" (TELES, 2006, p.51).

Teles (2006, p.41) aponta que existem outras interpretações para o conceito de gênero, constituídas pela teoria feminista pós-estruturalistas com intuito de quebrar paradigmas de que o corpo é entidade "biológica universal" e estudá-lo como construção social, cultural, linguística e sob a ótica das relações de poder.

Por sua vez, Louro et al. (2007, p.16) defende que há quatros modos de teoria de gênero como ferramenta teórica e política:

1) o gênero aponta para a ideia de que o processo de formação de homens e mulheres é inconsistente, incompleto e está em constante mudança. A ligação entre gênero e educação revela que a complexa prática de educar vai além dos processos familiares e escolares, pois inclui a influência dos meios de comunicação; 
2) existem várias formas de se conceituar e viver a feminilidade e a masculinidade. Cultura, classe, etnia, sexualidade, religião e nacionalidade funcionam como produtoras de sentidos múltiplos que constroem e diferenciam corpos e sujeitos. Podem existir várias vivências e experiências de diferentes formas dentro do mesmo grupo ou até no mesmo indivíduo;

3) o conceito não visa apenas o estudo das mulheres, pois traz implícitas as análises de relação de poder entre homens e mulheres;

4) o conceito passa a ter um foco mais amplo, em que surge a necessidade de observar os diferentes modos pelos quais o gênero age sobre o social, analisado por meio de símbolos, instituições sociais, normas, conhecimentos, leis, políticas etc.

Diante disso, o estudo de gênero revela que se devem considerar todos esses desdobramentos para entender e discutir a questão da desigualdade de gêneros articulada com análise ampla dos processos sociais, culturais, políticas, leis, meios de comunicação, raça, classe social, aparência física etc.

Segundo Louro et al. (2007), no início da década de 1970, os estudos de gênero foram deslocados da biologia para a cultura e a sociedade, já que elas representam

[...] os modos pelos quais características femininas e masculinas são representadas como mais ou menos valorizadas, as formas pelas quais se reconhece e se distingue feminino de masculino, aquilo que se torna possível pensar e dizer sobre mulheres e homens, que vai constituir, efetivamente, o que passa a ser definido e vivido masculinidade e feminilidade, em uma dada cultura, em um determinado momento histórico (LOURO et al., 2007, p.14).

Por isso, gênero se constrói socialmente e depende da época e história de cada sociedade. Assim, percebe-se que a própria sociedade modifica as diferenças sexuais, gerando a desigualdade. Além disso, a importância do estudo de gênero não só contribuiu para análises das relações sociológicas, como levantou informações estatísticas das situações de vida das mulheres e colocou em discussão as diferenças e desigualdade social entre o homem e a mulher.

\section{Publicidade e gênero}

Ao estudar publicidade e gênero, importa-nos desvendar que a publicidade utiliza diversas linguagens nas identificações do gênero feminino e masculino. Por meio das condutas sociais, políticas, religiosas, as tendências comportamentais representadas na sociedade foram construindo as relações de gênero no contexto publicitário. A 
publicidade funciona como um mecanismo que reforça, cria e promove os discursos de gênero.

Em concordância com Mendes (2009, p.244), enquanto o movimento feminista procurava quebrar estereótipos enraizados nas práticas culturais, sociais e psicológicas, a publicidade realiza o papel inverso: naturaliza as divisões de papéis entre mulheres e homens, reproduzindo uma visão conservadora em seus anúncios. A partir da ideia de Louro et al. (2007, p.152), é necessário entender que a publicidade produz, sustenta e transforma os discursos de gênero, uma vez que

[...] as relações de gênero representadas pela mídia são campos de constituição de identidades, de produção e reprodução de representações e, portanto, espaço educativo onde imagens de crianças, adolescentes, mulheres e homens podem ser consumidas, tendo como referencial o modelo social, econômico e cultural hegemônico.

A publicidade possui discursos sugerindo prazer e diversão, mas que também carrega significados que educam e reproduzem conhecimento, contribuem como um mecanismo na construção e formação de identidades sexuais e de gênero. Pode-se dizer que a construção da publicidade apenas reforça os significados apreendidos pelo sujeito, pois "seu discurso, suas representações, estão sempre relacionados com o conhecimento que circula na sociedade; suas imagens trazem sempre signos, significantes e significados que nos são familiares" (LOURO et al., 2007, p.150).

É importante o estudo de gênero na publicidade para identificar os signos relacionados ao gênero e à sexualidade. Assim, ela contribui para o discurso ideológico (social, cultural, histórico e psicológico) segundo o qual homens e mulheres ocupam lugares distintos na sociedade, "uma vez que [as peças publicitárias] são constantemente produzidas e reproduzidas com a ligação de homens com o trabalho e da mulher com adjuntos afetivos" (KNOLL, 2012, p. 250). Na publicidade, normalmente a mulher aparece como mãe e dona do lar, disponível para mobilizar o desejo masculino, e o homem atua como provedor do lar e portador de virilidade. Deve-se destacar ainda o predomínio de um modelo tradicional de família (geralmente, são mostrados o homem, a mulher, duas crianças e o animal de estimação). Observar anúncios sob o ponto de vista de gênero e sexualidade revela que

[...] é possível identificar de que formas são socialmente construídos tipos de corpos, modo de viver, comportamentos e valores apresentados nas imagens. Também [é] possível entender como sujeitos podem ser constituídos a partir de um modelo predominante, correspondente ao sistema político, social, cultural no qual estão inseridos (LOURO et al. 2007, p.152). 
A utilização da imagem de diferentes pessoas serve para vender os mais diversos produtos, e estas carregam sentidos simbólicos socialmente construídos, que têm como intenção constituir identidades. Por isso, a publicidade traz signos dominantes geralmente relacionados ao cotidiano, fazendo com que as pessoas se identifiquem com a imagem e passem a consumir, além do produto, os valores embutidos sobre o corpo, comportamento, hábitos, modo de pensar, vestir etc.

\section{A beleza "natural" na campanha da Dove}

A partir dos resultados de pesquisas de mercado, a Dove, marca pertencente à gigante da área de cosméticos Unilever, vem explorando em suas campanhas um nicho voltado para a diversidade da beleza feminina. Desde 2006, apresenta seis campanhas que utilizam como estratégia o discurso segundo o qual não existe um modelo ideal de beleza feminina; cada mulher possui a sua própria, procurando mostrar que a beleza é uma questão de confiança. Foram apresentadas até 2013 quatro campanhas em formato de vídeo (Retratos da Real Beleza, Campanha Dove Pela Real Beleza, Dove - Evolution Commercial e Câmera Tímida).

O anúncio Câmera Tímida foi publicado em 2013. Foi elaborado pela Ogilvy \& Mather de Londres, e veiculada no Brasil em 7 julho de 2013 no Youtube, chegando a 4.000.907 de visualizações. Na plataforma Facebook, o comercial foi inserido com o título "Seja confiante e não tenha medo de celebrar a sua beleza", em 10 julho 2013, chegando a 7.103 .558 de curtidas, 558 comentários e 799 partilhas naquele ano.

A opção de veiculação em redes sociais justifica-se porque esse espaço funciona como um mecanismo para levar a informação instantaneamente a diferentes públicos, possibilitando que o receptor participe e interaja com a marca, serviço e produto. Com o rápido crescimento no Brasil, as redes sociais atraem interesses e investimentos publicitários para disseminar em tempo real suas campanhas.

O uso do meio online para fins publicitários cresce aceleradamente. Em termos de receitas publicitárias, a internet perde apenas para a TV por assinatura, jornal e TV aberta. Dessa forma, a marca Dove utiliza o Youtube como estratégia para atingir, com a Campanha pela Beleza Real, o maior número de pessoas possível. Primeiramente, a Dove realizou diversas pesquisas, e uma delas teve por objetivo compreender como as mulheres se sentem frente às câmeras. Um estudo feito com 4.075 mulheres de 18 e 64 anos de várias partes do mundo, revelou que muitas delas se escondem de fotografias por não se sentirem bonitas e confiantes. Segundo informações do Portal da Propaganda (2013), 
[...] 77\% das mulheres declararam ter vergonha da câmera; $36 \%$ das mulheres admitem terem se tornado mais tímidas frente às câmeras entre 11-20 anos de idade; $55 \%$ das mulheres admitem que são mais tímidas na frente da câmera agora, do que eram 10 anos atrás. Mais da metade das mulheres (57\%) admitiu que a preocupação com sua aparência pode ter um impacto negativo em seu comportamento em frente de uma câmera.

Câmera Tímida tem duração de 1 minuto e mostra câmeras subjetivas em ação flagrando mulheres de todas as idades. Nas cenas aparecem adolescentes, jovens, adultas e senhoras se escondendo da câmera, com as mãos e objetos ocultando o rosto na tentativa de camuflar sua própria beleza. $\mathrm{O}$ filme visa mostrar a ideia de que as mulheres não se sentem confiantes com sua própria imagem. Dove propõe o seguinte questionamento: quando você parou de se achar bonita? No final aparecem imagens de crianças alegres, desinibidas frente à câmera. Dove leva as mulheres a questionarem por que sentem ansiedade e frustações com sua aparência na fase jovem e adulta, já que, quando eram crianças, a beleza era encarada de uma forma mais natural por elas.

Para entender as mensagens do vídeo Câmera Tímida, optamos pela metodologia da análise de conteúdo, que tem como intuito fazer com que o receptor descodifique e compreenda a mensagem referida, o pensamento do sujeito, dentro do discurso emitido pelo referente. Trata-se de uma forma de análise que pressupõe a construção de categorias que podem ser definidas "como grandes enunciados", ou conjunto de "temas", permitindo a realização de observações amplas, aprofundadas (BARDIN, 2009).

Para esta pesquisa, foram desenvolvidas as seguintes categorias para análise do vídeo: personagens, ambientação, ação e persuasão.

\section{Personagens}

A propaganda de cunho institucional tem como finalidade promover a imagem e marca da instituição, provocar mudança no comportamento. Segundo Cabral (1986, p. 89), campanha institucional "[...] a rigor, é aquela que se destina a institucionalizar a marca. Aqui não existe a preocupação com a venda do produto em si, não há preocupação de levar o mercado a comprar tantas unidades do produto. A preocupação é com a marca e não com o modelo".

O vídeo Câmera Tímida visa provocar uma ação no receptor diante do problema, pois almeja comunicar a mensagem de forma eficaz para o público feminino, modificar seu pensamento e comportamento em relação à insegurança com a própria beleza. 
No vídeo há a participação de 35 personagens, mulheres comuns de todas as feixas etárias. No início, são mostradas adolescentes, jovens, adultas, senhoras, e o vídeo finaliza com crianças. Observa-se a ênfase nas personagens adolescentes e jovens. Geralmente nesta fase inicia-se a pressão sobre beleza, e a desconfiança das mulheres com seu corpo e aparência.

De acordo com Santaella (2004), a mídia e a publicidade têm o papel de prometer a beleza e juventude "eternas". Por isso, a marca Dove utiliza de forma sutil a ferramenta de edição para disfarçar marcas e expressões do rosto, e por meio das modelos adolescentes e jovens, revela o estereótipo da juventude eterna. Não é à toa o enfoque principal nas faixas mais jovens. Segundo Freitas (2013, p.2), “crianças e adolescentes parecem ser cada vez mais 'treinados' para o consumo, para o conhecimento de marcas e para a lealdade com elas”. Assim, a marca Dove evidencia o público infanto-juvenil e jovem, contribuindo para a formação do consumidor, pois este tem poder de escolha, influência e decisão no consumo dos produtos na família.

Conforme Bardin (2009, p. 106), é possível analisar a unidade personagem a partir dos questionamentos "Quem e em que ocasião? Com que papel? Em que situação?” Das 35 personagens envolvidas, 6 são adolescentes, 13 jovens, 6 adultas, 5 senhoras e 5 crianças.

As adolescentes e jovens estão num contexto mais descontraído - na cama utilizando o telefone móvel, indo ao colégio, divertindo-se numa festa, indo à festa de formatura, sorridentes na sala a brincar com a cortina. Todas se revelam muito tímidas com a presença da câmera; algumas escondem o rosto com a mão e outras com objetos, mas todas sorriem e até mesmo dão gargalhadas, brincando na frente da câmera. Por sua vez, as adultas e senhoras estão em contextos que revelam obrigações e tarefas a cumprir - mulher na cozinha, a estudar ou trabalhar no laptop, no escritório. Há menos cenas descontraídas.

Identificam-se no filme signos que contribuem para a construção das relações de gênero. O filme mostra como deve ser o comportamento ideal feminino, utilizando-se das diversas situações em que as mulheres retratadas estão inseridas (quarto, cozinha, crianças vestidas como princesas ou brincando de casinha e boneca etc.).

Segundo Cruz et al. (2012, p.4), "percebemos uma conexão mais ancorada entre brinquedo e formação do gênero quando percebemos que ambos estão imbricados em relações de poder". Assim, como o poder está mais nas estratégias e táticas, a publicidade utiliza brinquedos como meio para a produção de significados que influenciam na 
formação de discursos de gênero na sociedade. Conforme análise no site da Dove, desde pequenas as meninas aprendem a ser autocríticas. Isso ocorre porque a mídia e a sociedade geram estes estereótipos.

Observa-se também a ênfase na imagem de modelos de cor branca e ou com pele morena clara - no vídeo aparecem apenas duas modelos negras. Assim, segundo Moreno (2008, p. 49), “[no] modelo social, a beleza é branca. Dificilmente há diversidade de raças e etnias entre os modelos de beleza apresentados. As modelos, as atrizes, as mulheres mostradas pela mídia são, em sua imensa maioria, brancas". Da mesma forma, não aparecem modelos acima do peso (supostamente) ideal. Em suma, Dove mantém uma postura conservadora quanto à diversidade das mulheres.

\title{
Ambientação
}

Para compreender a ambientação do vídeo, é importante destacar que

\begin{abstract}
As imagens audiovisuais são fantasmagorias em que o tempo da projeção [presente] não é o tempo do registro [passado], são imagens agentes que recordam um mundo abstrato de valores, sonhos e ideologias, ouvimos-vemos sons-imagens em composição com objetos bem definidos de marcar a alma, se fazer memória, permanecer para serem recordados posteriormente [futuro]. (CAMARGO (2013, p.18) apud ALMEIDA (1999, p. 62-63).
\end{abstract}

O cenário é composto por objetos com muita cor, fotos em mural, parede, geladeira e quadros, livros, brinquedos, equipamentos eletrônicos e utensílios de cozinha. Os movimentos das personagens são instantâneos quando percebem a presença da câmera. Além disso, tem-se a ênfase em ambientes íntimos e domésticos. As características dos objetos remetem a um cenário moderno, pertencente à classe média alta. Na sequência de planos, efeitos sonoros, música, imagens em movimento, o vídeo revela cenas em ambiente interno (no sofá, escritório de casa, na cama, cozinha e sala) e externos (na rua, em frente de casa, na discoteca, no jogo de boliche e no jardim).

Cada personagem está num contexto particular; os locais foram muito bem selecionados com a intenção de mostrar o dia a dia das mulheres, que revelam na sua intimidade os momentos descontraídos - seja lendo um livro, fazendo um jantar, acordando, saindo para o colégio etc. Quando elas percebem a câmera, automaticamente ocultam o rosto.

O estudo de gênero faz-nos identificar as divisões de papéis masculinos e femininos. Este comportamento se faz presente no vídeo, pois o ambiente no qual as mulheres se encontram revela estereótipos enraizados no imaginário social. Um exemplo 
é a $24^{\text {a }}$ cena, que apresenta uma mulher na sala estudando e trabalhando no laptop, o que remete à imagem de mulher moderna, mas ao mesmo tempo limitada ao ambiente doméstico. Já na $29^{a}$ cena nota-se uma senhora maquiada, reafirmando o convencionalismo de que a mulher deve estar sempre produzida para se sentir bonita.

Ghilardi-Lucena (2003) aponta que a publicidade nas últimas décadas incorporou conquistas femininas no mundo contemporâneo, como a inserção da mulher no mundo do trabalho, sua participação nas decisões familiares, entre outras. Porém, a publicidade retrata a mulher moderna ainda atrelada às tradicionais visões de gênero que a relacionam com os cuidados do lar, da família e da beleza. Essa representação contribui para naturalizar a dupla e tripla jornada de trabalho que elas realizam todos os dias e para a manutenção da desigualdade social entre os sexos na sociedade e na família.

Em análise partindo do ponto de vista de Santaella (2010), na última cena com enquadramento em plano médio aparece uma criança num ambiente com bonecas e brinquedos de "casinha". Segurando um espelho, ela se olha e em seguida sorri para a câmera. Segundo Santaella (2010, p. 145), “a criança antecipa o domínio do seu corpo, achando-se cativada, fascinada pela imagem no espelho e se rejubila. Por trás desse júbilo, entretanto, oculta-se um logro, fonte da alienação imaginária que perseguirá o humano para sempre".

Desta forma, a ambientação remete ao entendimento de que a criança ao se deparar com o reflexo identifica o seu "eu", mas na verdade o seu "eu" acaba por se formar a partir da imagem do outro. Isso reforça a ideia de que a menina tem que utilizar somente brinquedos feminizados. Nas últimas cenas com personagens infantis, nota-se primeiramente uma menina brincando com bambolê na cozinha, reforçando o estereótipo de que "lugar de mulher é na cozinha". Vê-se também uma menina toda produzida com vestidos e faixa com brilho no cabelo, sugerindo a ideia de que toda menina tem que estar sempre bonita. Na última cena, há várias bonecas, mesa de brinquedo com bolo e pratinhos, talheres e copinhos, sugerindo a brincadeira de "casinha", o cuidado do lar, da família.

\section{Ação}

De acordo com Barreto (2004, p.106), “qualquer que seja o tempo, todo roteiro precisa de força dramática, de impacto, de sedução e de outros elementos, a serem vistos, capazes de persuadir o consumidor”. A história do vídeo Câmera Tímida revela em um 
minuto a ação de uma câmera subjetiva indo ao encontro das pessoas nos ambientes íntimos e ocasiões espontâneas.

Observam-se nas cenas momentos em que as pessoas tímidas usam as mãos para tapar o rosto, ou também utilizam objetos que estão nas mãos ou próximos. Todas reagem à ação dizendo um "não" ou rindo alto; outras apenas tapam o rosto. Das 35 personagens, apenas 8 não sorriem para a câmera. Conforme Camargo (2013, p.9), existe a "recusa do demasiado pleno e do demasiado próximo. Recusa inconsciente, reflexo da autodefesa diante do insustentável". Por isso, as mulheres se retraem quando vigiadas, porém não só pelo motivo de não se sentirem bem consigo mesmas - fraca autoimagem, baixa autoestima, fobia, distúrbio de personalidade —, mas também pela surpresa e invasão de privacidade.

Numa sequência lógica, o enquadramento segue mais no plano médio (10 cenas), plano próximo (16 cenas), ainda inclui quatros cenas no plano inteiro (revela a pessoa da cabeça aos pés), cinco cenas em close (ênfase no rosto inteiro, do ombro para cima) e uma cena em superclose (enquadramento do queixo até a cabeça).

A ênfase no enquadramento de plano médio (retrata a pessoa da cintura para cima) tem como finalidade mostrar a linguagem corporal, o movimento da mão indo ao rosto ou na frente da lente, além da composição do cenário. Já o plano próximo (mostra a pessoa a partir do busto) tem como objetivo evidenciar as características, intensões e atitudes das personagens. A ideia do enquadramento aproxima e reforça a dramatização presente no rosto e olhar das personagens, provocando os sentidos do público-alvo.

Segundo Camargo (2013, p.20), é através das mudanças de planos que "percebemos que o aparente vazio, imperceptível ao olhar consciente, o entre-planos, é onde acontece a significação do filme. O corte entre os planos é o espaço mítico onde se encontra o fantástico". Por isso, o filme com as mudanças de imagens num corte ligeiramente seco, e com imagens de meninas e mulheres arremessando objetos sobre a câmera, além das cenas onde elas fecham a porta "na cara", são ações que funcionam como elementos que dramatizam a situação, com intenção de causar impacto e seduzir o consumidor.

Segundo o ponto de vista de Camargo (2013), "é no corte das imagens que as relações semânticas e sintáticas dos filmes audiovisuais se complementam, fazem (ou recebem) sentido". Por isso, no intervalo de 43 segundos de filme aparece "fade" com a mensagem: “Quando você parou de se achar bonita?", que funciona como uma forma de 
mudança de sentido, pois antes as mulheres apareciam com sensações de vergonha e timidez frente à câmera. Logo em seguida irradiam as cenas de crianças sorrindo, dançando, olhando-se no espelho e expondo-se para a câmera. Finaliza com o logotipo da Dove e o slogan "Revele sua beleza real".

\section{Persuasão}

Partindo da ideia de que a publicidade utiliza diversos discursos e linguagens comerciais, a campanha institucional da Dove tem como intuito provocar mudanças na imagem da marca e no comportamento do público, utilizando-se de estratégias de persuasão para incentivar meninas e mulheres a melhorar da autoestima e perceber que a beleza é uma questão de confiança. Segundo Carvalho, a linguagem persuasiva se dá por meio das palavras e tem a capacidade de criar, destruir, prometer e até negar uma ideia, poder para influenciar ou não em uma atitude e ação. Seguindo o modelo de linguagem de Roman Jakobson, a comunicação deste processo tem duas funções: a interacional e diretiva (CARVALHO, 2001, p. 16).

Um exemplo disso é a interrogação: "Quando você parou de se achar bonita?", que tem foco na função interacional. Além disso, tem por objetivo usar a função diretiva, pois tem como objetivo influenciar na atitude e emoção do receptor, funcionando como um pedido para a mulher adolescente e adulta deixar a ansiedade e frustração em relação à sua beleza. A mensagem expõe de forma sutil que as mulheres adolescentes, jovens e adultas se escondem das câmeras por não se sentirem tão bonitas como eram quando crianças. Nas entrelinhas, a mensagem sugere que a sociedade e mídia impõem padrões a ser reproduzidos, por isso muitas não se sentem bonitas consigo mesmas.

\section{Considerações finais}

A publicidade contribui para a formação da identidade de gênero. Utiliza-se de signos, elementos, linguagens e técnicas que reforçam a divisão do gênero masculino com o feminino. Os estereótipos do que é ser homem e mulher são reflexos preestabelecidos no imaginário social, e a publicidade promove e reforça esses discursos. A marca Dove colabora para a manutenção dos papéis femininos, pois evidencia estereótipos no vídeo Câmera Tímida, ainda que de forma atenuada.

No vídeo o discurso pretende convencer a mulher de que ela deixou de se achar bonita quando parou de se sentir bem com ela mesma, e para isso precisa se embelezar. 
Há várias indicações da reprodução de estereótipos por meio da beleza feminina, do consumo e da feminilidade, como a menina tocando no cabelo, olhando-se no espelho, a menina com vestido e laço no cabelo. Além disso, o vídeo revela que, ao assumir as obrigações do dia a dia, a mulher deixou de cuidar da aparência, por isso a marca indica que, para elas ficarem com a pele macia e cuidada como a das crianças, têm que usar o produto da marca Dove.

A publicidade informa, seduz, manipula, ordena e promove os discursos por meio de signos predominantes, nomeadamente de conhecimento cotidiano. Utilizam-se como estratégias recursos estilísticos e argumentativos para transformar atitudes, valores, pensamentos e estilos de vida para vender o sonho de felicidade sem máculas. A campanha institucional utiliza como uma de suas estratégias a linguagem emocional. Ela sugere que a mulher olhe para si própria e lembre o quanto era desinibida quando criança, a fim de restabelecer a confiança e autoestima em relação a sua beleza.

Diante das técnicas de persuasão e sedução, vimos que o vídeo se apropriou no discurso presente no cotidiano. Um exemplo disso é a utilização da brincadeira de esconde-esconde, enraizada na cultura ocidental, como linha condutora da narrativa. Além disso, o texto em lettering transmite sentimento e conteúdo.

A marca utiliza como estratégia de veiculação o Youtube e o Facebook, que disseminam a informação de forma rápida e global. As mídias sociais têm essa praticidade e flexibilidade de interação e participação do público com a marca, funciona também como uma forma de as pessoas se informarem sobre o produto antes de adquiri-lo. A marca pretende com a campanha revelar a beleza "real" das mulheres, mas utiliza recursos que denotam que as personagens pareçam levemente maquiadas, inclusive os lábios das adolescentes e criança estão mais rosados. Assim como diz Eco (2010), a publicidade não tem como objetivo revelar a beleza natural, mas pretende transferir ao observador prazer e jovialidade. Desta forma, Dove, ainda que de uma forma não agressiva, contribui para a construção o ideal de beleza de consumo. Além disso, questões relacionadas à aparência e estética nunca foram tão contempladas como hoje, principalmente no universo feminino, por cultuar e dedicar muito tempo e dinheiro em busca da beleza revelada pela sociedade e visibilizada na mídia.

\section{Referências}

BARDIN, Laurence. Análise de conteúdo. Lisboa: Edições 70, 2009. 
BARRETO, Tiago. Vende-se em 30 segundos: manual do roteiro para filme publicitário. São Paulo: Editora Senac, 2004.

CABRAL, Plínio. Propaganda: técnica da comunicação industrial e comercial. São Paulo: Editora Atlas, 1986.

CARVAlHO, Nelly. Publicidade: A Linguagem da Sedução. São Paulo: Ática, 2004.

CAMARGO, Hertez Wendel. O filme publicitário como mito atualizado: fantasia, ritual, tempo e totemismo. Disponível em: http://www.bocc.ubi.pt/pag/camargo-hertez2013-filme-publicitario.pdf. Acesso em: 16 novembro de 2014.

CRUZ, Lilian Moreira, SILVA, Zenilton Gondim, SOUZA, Marcos Lopes de. O brinquedo e a produção do gênero na educação infantil: uma análise pósestruturalista. Disponível em: file:///C:/Users/-Jussara-/Downloads/3880-6394-1PB\%20(2).pdf. Acesso em: 15 novembro de 2014.

ECO, Umberto. História da Beleza. Rio de Janeiro: Record, 2004.

FREITAS, Patrícia Oliveira de. Relações de Gênero: Olhares para publicidade de brinquedos direcionada aos meninos. Congresso da Intercom. Manaus, 4 a 7 setembro de 2013. Disponível em: http://www.intercom.org.br/papers/nacionais/2013/resumos/R81762-1.pdf. Acesso em: 18 novembro de 2014.

GHILARDI-LUCENA, Maria Inês. Representações do feminino. Campinas: Átomo, 2003.

KNOLL, Graziela Frainer. Discursos de gênero na publicidade: análise crítica de textos publicitários em revistas. Santa Maria: Sociais e Humanas, v. 25, jul./dez. 2012, p. 239252.

LOURO, Guacira Lopes; NECKEL, Janes Felipe; GOELLNER, Silvana Vilodre. (Organizadoras). Corpo gênero e sexualidade: um debate contemporâneo. 3. Ed. Petrópolis: Vozes, 2007.

LOURO, Guacira Lopes. Gênero, sexualidade e educação. Uma perspectiva pósestruturalista. Petrópolis: Vozes, 1997.

MENDES, Débora. A ideologia de gênero na publicidade contemporânea. Mediações revista de Ciências Sociais. UEL. Londrina, v. 15, n.1, p. 241-257, Jan/Jun. 2010.

MORENO, Rachel. A beleza impossível: mulher, mídia e consumo. São Paulo: Ágora, 2008.

SANTAELLA, Lucia. Corpo e comunicação: sintoma da cultura. São Paulo: Paulus, 2004.

Learning, 2010.

Estratégias semióticas da publicidade. São Paulo: Cengage

TELES, Maria Amélia da Almeida. O que são direitos humanos das mulheres. São Paulo: Brasiliense, 2006. 